\title{
Desmodium tortuosum, Euphorbia heterophylla and Moringa oleifera Effect on Local Rabbit Does Milk Production and Pups' Performances
}

\author{
Koffi Mathurin Konan ${ }^{1}$, Tagouèlbè Tiho ${ }^{2}$, Gningnini Alain Koné2 ${ }^{2}$ Nogbou Emmanuel Assidjo ${ }^{2}$, \\ Maryline Kouba ${ }^{3} \&$ Pierre Guy Marnet ${ }^{4}$ \\ ${ }^{1}$ Agropastoral Management Institute, Peleforo Gon Coulibaly University, Korhogo, Côte d'Ivoire \\ 2 Laboratory of Animal Science, Department of Agriculture and Animal Resources, National Polytechnic \\ Institute Felix Houphouët-Boigny, Yamoussoukro, Côte d'Ivoire \\ ${ }^{3}$ UMR 1348 PEGASE, INRA-AGROCAMPUS, 65 rue de Saint Brieuc, 35042 Rennes Cedex, France \\ ${ }^{4}$ Unité SPA, Institut Agro-Campus Ouest, F-3500 Rennes, France \\ Correspondence: Koffi Mathurin Konan, Agropastoral Management Institute, Peleforo Gon Coulibaly University, \\ B.P. 1328, Korhogo, Côte d'Ivoire. Tel: 225-07-075-714-7614. E-mail: mathurink@upgc.edu.ci
}

Received: January 27, 2021

Accepted: February 28, 2021

Online Published: March 15, 2021

doi:10.5539/jas.v13n4p93

URL: https://doi.org/10.5539/jas.v13n4p93

\begin{abstract}
Desmodium tortuosum and Euphorbia heterophylla are fields' weeds. Moringa oleifera plant is adapted to several agroecological zones and has many food and medicinal virtues. This work assessed these three plants potential to induce milk production. Thus, 96 primiparous local breed rabbit does, 10 months old, with an average 2983.6 $\pm 212.4 \mathrm{~g}$ weight were used. They were grouped into 4 blocks containing 24 animals each. Then, one diet among 4 diets was randomly assigned to each group. Panicum maximum as fodder was mixed with a commercial pellet rabbit feed, the control (Pan). Then, this control diet was supplemented with Desmodium tortuosum (Des), Euphorbia heterophylla (Eup) and Moringa oleifera (Mor) in pellet partial substitution. The parameters monitored were the litter size, the pups' average daily weight gain, the does' weights before and during gestation, and after farrowing. Likewise, the milk production at peak lactation was evaluated. As a result, compare to Pan, Des, and Eup diets improved the total rabbit pups' number from 96 to 112, and it represented a $16.67 \%$ gain. But Mor diet reduced Pan diet performance to 76 newborn rabbits, it was a $20.83 \%$ loss. Moreover, Des, Eup, and Mor diets induced an improvement in the milk quantity at peak lactation. In this order, these improvements were $+15.51,+27.74$, and $+19.98 \%$, respectively, compared to Pan diet which produced $109.6 \mathrm{~g}$. In conclusion, Desmodium tortuosum and Euphorbia heterophylla could be used as green forages to improve milk production in local rabbit does breeding.
\end{abstract}

Keywords: Desmodium tortuosum, Euphorbia heterophylla, Moringa oleifera, rabbit does, litter size, milk production

\section{Introduction}

In African flora, several plants are used for therapeutic and food purposes. Accordingly, Yapo et al. (2012) demonstrated Parkia biglobosa leaves aqueous extract immunostimulant activity in rabbits. Again, Kouakou et al. $(2015,2016)$ came to the conclusion that Euphorbia heterophylla, and Ipomea batatas leaves and stems can be used as supplements in rabbit and guinea pig diets. These leaves induce a good organic matter digestibility while promoting a significant reduction in production costs. Given the resulting animal products' good nutritional quality in terms of their polyunsaturated fatty acids content, HDL cholesterol contents, and high antioxidant power, these species are also recognized for their dietary and medicinal properties (Kouakou et al., 2015, 2016; Kouassi et al., 2017). Moreover, plants with galactogenic effects are also medicinal plants that are widely used in rural areas where breast milk remains the main route for babies' breastfeeding. For example, Sepehri et al. (1992) observed that crude and partially purified extract injection of coma (Sideroxylon celastrinum), flax (Linum usitatissimum), and cotton (Gossypium hirsutum) intravenously to sheep induced the prolactin secretion. Codjia et al. (2001), Deleke-Koko et al. (2011), and Akouedegni et al. (2012) identified steroidal constituents, terpenes, cardiotonic derivatives, saponins, and tannins presence in Adansonia digitata leaves. These metabolites would contribute to its lactogenic effect. 
Herein work hypothesis was that "Desmodium tortuosum, Euphorbia heterophylla and Moringa oleifera green forages would act on local rabbit does zootechnical and their litters performance". Thus, the main objective was to evaluate these green forages galactogenic effect served with a commercial mixed granulated feed for rabbits. The specific objectives were the local rabbit does dry matter digestibility evaluation, the milk production at the lactation peak, and the young rabbits' average daily weight gain.

\section{Materials and Methods}

The experiment was carried out from April to June 2019, at the experimental farm of the National Polytechnic Institute Felix Houphouët Boigny (INP-HB). Specifically, the essay was established at the laboratory of Zootechnics and Animals Productions, at Yamoussoukro $\left(6.5^{\circ} \mathrm{N} ; 5.2^{\circ} \mathrm{W}\right)$ in Côte d'Ivoire (Ivory Coast). During the test, the average temperature was $29.6 \pm 1.2{ }^{\circ} \mathrm{C}$, and the relative humidity fluctuated between $76.7 \pm 2.3 \%$ and $79.0 \pm 4.2 \%$. Finally, this period's average monthly rainfall was $111.6 \pm 15 \mathrm{~mm}$.

\subsection{Animals and Housing}

The animals were bred and slaughtered in accordance with the regulations for the care and use of research animals, according to European Directive 86/6096. The National authorization to experiment on live animals' number 3502 was issued to Maryline Kouba by the French Ministry of Agriculture. This regulation is accepted and applied in Côte d'Ivoire. So, ninety-six (96) multiparous local breed rabbits (Oryctolagus cuniculus), with an average weight of $2983.6 \pm 212.4 \mathrm{~g}$ and 10 months old were used. Four groups of 24 rabbits does each were set. The rabbits were randomly distributed to individual maternity cages. The cages had $108 \mathrm{dm}^{3}$ volume $(90 \mathrm{~cm} \times 40 \mathrm{~cm} \times 30 \mathrm{~cm}$, respectively for length, width and height) standing wire mesh, in a covered, and very well-ventilated rearing building. Each group was subjected to one of the four diets studied throughout the experiment. Thus, eight males with an average $2984.6 \pm 213.4 \mathrm{~g}$ weight were used for breeding.

\subsection{Feed Ingredients Chemical Analyzes}

The diet ingredients (pellet (FACI, Abidjan, Côte d'Ivoire) and green fodder) to be tested have been analyzed. These analyses consisted of dry matter (DM), ash, fat, protein, and crude fiber (CF) determinations. Total fiber contents were determined using the Fibertec System hot extractor. In addition, all the analyzes were carried out according to AOAC (1990). In addition, the ingredients, their total carbohydrate and their associated metabolizable energies (M.E.) were determined according to FAO (2003) approach (Table 1).

Table 1. Chemical composition of experimental diets' ingredients

\begin{tabular}{llllll}
\hline Composition (\%DM) & Desmodium tortuosum & Euphorbia heterophylla & Pellet & Moringa oleifera & Panicum maximum \\
\hline Dry matter & 22.9 & 17.4 & 90 & 13.3 & 25.8 \\
Organic matter & 89.3 & 91.8 & 90.1 & 88.6 & 90.7 \\
Ash & 10.7 & 8.2 & 9.6 & 11.4 & 9.3 \\
Crude fiber & 24.9 & 17.1 & 14.6 & 24.0 & 17.4 \\
Protein & 19.5 & 16.5 & 16 & 22.7 & 10.2 \\
Fat & 2.4 & 2.3 & 3.3 & 2.8 & 2.0 \\
Total carbohydrate & 67.4 & 73.0 & 71.1 & 63.1 & 78.5 \\
M.E. $(\mathrm{kcal} / \mathrm{kg} \mathrm{DM})$ & 3082.86 & 3201.21 & 3204.88 & 3040.91 & 3218.73 \\
\hline
\end{tabular}

Note. M.E.: Metabolizable Energy.

Total Carbohydrate $($ Tot_Carb $)=100 \%($ Protein + Fat + Water + Ash $)($ FAO, 2003)

M.E. $(\mathrm{kcal} / \mathrm{kg} \mathrm{DM})=[2.44 \times$ Protein $(\% \mathrm{DM})+8.37 \times$ Fat $(\% \mathrm{DM})+3.57 \times$ Tot_Carb $(\% \mathrm{DM})] \times 10(\mathrm{FAO}$, 2003).

\subsection{Experiments Procedure}

The tests lasted 81 days divided into 3 periods, including adaptation to the experimental environment for 23 days, gestation which lasts 30 days, and the young rabbits suckling lasted 28 days. The rabbit does mating was done after the adaptation period. Then, the diets were made by one control and three experimental diets. The control was composed of Panicum maximum Orstom G23 variety and some mixed rabbit pellets bought from FACIC (Pan). Next, the experimental diets were made of a control diet associated with Euphorbia heterophylla (Eup), Desmodium tortuosum (Des), and Moringa oleifera (Mor) (Table 2). All ingredients were collected in the wild, under natural conditions. The herbs such as Euphorbia heterophylla and Desmodium tortuosum were cut at $5 \mathrm{~cm}$ 
upper to the ground. But, Moringa oleifera fresh branches were cut at different positions depending on their position on the tree. Every day, the ingredients were weighed and distributed in order to evaluate the food intake. The minimum required quantities per animal and per day have been increased so that they become ad libitum. The collected green fodder was cleaned with potable water containing $2 \%$ bleach, pre-dried under the sun for half a day. Then, they were served the next day at $8 \mathrm{a} . \mathrm{m}$. Thus, the parasite pressure was reduced a little bit. Unfortunately, this pre-dried process was not possible with Moringa oleifera. In fact, Moringa oleifera leaflets were coming off from the branches during the pre-drying process. So, Moringa oleifera forage was harvested, cleaned, and served daily. Finally, the pellets were given in the afternoon (5 PM).

Table 2. Diets, ingredients, distributed amounts, ingredient incorporation and diet characteristics

\begin{tabular}{|c|c|c|c|c|c|c|}
\hline Diet & Ingredients & Distributed amounts & Incorporation rate $(\%)$ & Fat $(\% \mathrm{DM})$ & Protein $(\% \mathrm{DM})$ & M.E. (kcal/kg DM) \\
\hline \multirow{2}{*}{ Pan } & Panicum & 116.14 & 51.98 & \multirow{2}{*}{2.63} & \multirow{2}{*}{12.99} & \multirow{2}{*}{3212.58} \\
\hline & *Pellets & 107.30 & 48.02 & & & \\
\hline \multirow{3}{*}{ Des } & Panicum & 232.29 & 57.11 & \multirow{3}{*}{2.32} & \multirow{3}{*}{13.66} & \multirow{3}{*}{3179.41} \\
\hline & *Pellets & 61.34 & 15.08 & & & \\
\hline & Desmodium & 113.10 & 27.81 & & & \\
\hline \multirow{3}{*}{ Eup } & Panicum & 116.14 & 19.87 & \multirow{3}{*}{2.30} & \multirow{3}{*}{15.22} & \multirow{3}{*}{3205.70} \\
\hline & *Pellets & 30.17 & 5.16 & & & \\
\hline & Euphorbia & 438.22 & 74.97 & & & \\
\hline \multirow{3}{*}{ Mor } & Panicum & 232.29 & 51.69 & \multirow{3}{*}{2.48} & \multirow{3}{*}{15.30} & \multirow{3}{*}{3157.50} \\
\hline & *Pellets & 64.20 & 14.29 & & & \\
\hline & Moringa & 152.86 & 34.02 & & & \\
\hline
\end{tabular}

Note. M.E.: Metabolizable Energy.

Total Carbohydrate $($ Tot_Carb $)=100 \%($ Protein + Fat + Water + Ash $)($ FAO, 2003) .

M.E. $(\mathrm{kcal} / \mathrm{kg} \mathrm{DM})=[2.44 \times$ Protein $(\% \mathrm{DM})+8.37 \times$ Fat $(\% \mathrm{DM})+3.57 \times$ Tot_Carb $(\% \mathrm{DM})] \times 10(\mathrm{FAO}$, 2003).

* These FACI pellets were made of corn, corn bran, coconut meal, cottonseed meal, molasses, and limestone premix.

\subsection{Feed Intake and Apparent Digestive Utilization Coefficient}

The refusals were collected daily, weighed, and placed in an oven at $70{ }^{\circ} \mathrm{C}$ to estimate their dry matter content (DM). Thus, the voluntary dry matter (DM) amount ingestion could be assessed. Using a scale (Haier, Qingdao, China, model-332L, maximum $5000 \mathrm{~g}$, precision $1 \mathrm{~g}$ ), the rabbit does' body weights were recorded weekly throughout the experimental period. Similarly, another small scale (Kern, Balingen, Germany, model WLPC6S, maximum $3000 \mathrm{~g}$, precision $0.01 \mathrm{~g}$ ) was used to weigh the young rabbits at birth and weekly until age 28 days. So, these weight records helped to assess the rabbit does and young rabbits' average daily weight gain (ADWG) during the lactation. Also, each rabbit doe's droppings were collected and recorded daily after the third week of gestation $\left(22^{\text {nd }}\right.$ to $26^{\text {th }}$ days $)$ and their DM content was evaluated in order to determine the apparent digestive utilization coefficient (1). In detail, during 5 days, at 8 A.M, 5 rabbit does were randomly selected per diet. Thereafter, their droppings were collected. Just after collection, they were weighed fresh, then taken to an oven and dried at $105{ }^{\circ} \mathrm{C}$ for 24 hours, separately according to each rabbit doe. After the drying, the feces of each rabbit doe were weighed. So, an average apparent digestive utilization coefficient was computed per diet, based on the 5 data.

$$
\text { DUC }(\%)=[(\text { Feed intake }- \text { Feces }) / \text { Feed intake }] \times 100
$$

\subsection{Milk Production}

Pups rabbits' numbers were equalized to six per rabbit does within each group immediately after birth by adding or removing newborn rabbits. The milk production was estimated during the entire breastfeeding period. The day before measurement days, each rabbit does was separated from her young rabbits from 6 P.M. to 7 A.M. To begin, each rabbit does was weighed. Then, the newborns were put together with the rabbit does for 15 minutes. To end, each rabbit does was weighed again after the breastfeeding. So, the change in weight decrease before and after breastfeeding corresponded to the daily milk production (Lebas, 1971; Zerrouki et al., 2012). 


\subsection{Statistical Analysis}

Data were analyzed by the one-way analysis of variance (ANOVA) option of the generalized linear model (GLM) of XLSTAT version 2014, 2014.5.03 (Copyright $^{\circ}$ 1995-2014 Addinsoft Sarl, Paris, France) as 2 treatments with diet as main effects. The statistical model used was $Y_{i k}=\mu+D_{i}+R_{i}+\gamma_{i k}$, where, $Y_{i k}=$ response variables from each individual replication or pen, $\mu=$ the overall mean; $D_{i}=$ the effect of diet; $R_{i}=$ the inter-experimental unit (replications) error term; and $\gamma_{\mathrm{ik}}=$ the intra-experimental unit error term (Koné et al., 2020). Least significant difference comparisons were made between treatment means for main effects when there was a significant $\mathrm{F}$ value. Significance implies $\mathrm{P}<0.05$, unless stated otherwise.

\section{Results and Discussion}

\subsection{Diets Digestibility}

The diet digestibility is presented in Table 3. The dry matter (DM) voluntary daily intake means by Rabbit does subjected to Pan, Des, Eup, and Mor diets were significantly different. Indeed, rabbits does under Des and Pan diets were significantly higher than those of Eup and Mor diets. Numerically, Des and Pan diets led to $122.2 \mathrm{~g}$ per day on average. Based on dry matter ingestion, among D. tortuosum, E. heterophylla, M. oleifera, and $P$. maximum experimental diets, E. heterophylla was the most ingested forage for 68.3 and $70.1 \mathrm{~g} / \mathrm{d}$, respectively during gestation and lactation. While, M. oleifera was the less ingested for 12.3 and $24.3 \mathrm{~g} / \mathrm{d}$, respectively during gestation and lactation. Looking at P. maximum in different diets, its highest intake level was observed with Des diet for 46.5 and $51.7 \mathrm{~g} / \mathrm{d}$ during the gestation and lactation, respectively. On the contrary, the lowest level was obtained with Eup, for 18.2 and $19.9 \mathrm{~g} / \mathrm{d}$, in the same physiological period order. Singularly, P. maximum ingestion levels in Pan and Mor diets were not significantly different; 34 and $32.7 \mathrm{~g} / \mathrm{d}$, respectively, during gestation $(\mathrm{P}>0.05)$.

A careful look at the voluntary daily intake of metabolizable energy shows an increase from gestation to lactation. So, from 391.5 to $425.98 \mathrm{kcal}$ per day, Pan diet energy intake increased by $8.81 \%$. Similarly, Des diet energy intake increased by $7.12 \%$, from 390.44 to $418.28 \mathrm{kcal}$ per day. This increase in energy intakes from gestation to lactation was reported by Fernández-Carmona et al. (2003). Again, metabolizable intake increased with Eup diet by $9.94 \%$ by moving from 341.74 to 375.71 kcal per day. Finally, increasing from 327.96 to 391.4 kcal per day, the energy consumption in Mor diet rose up by $19.34 \%$.

The observed differences in daily dry matter intake during the lactation period were linked to the variations in diets' pellet quantities. Its quantities derived from calculus which aimed to provide iso-protein and iso-energetic diets. In all diets, the pellets were fully consumed, and the animals compensated the lacks with Panicum maximum and the test forage. So, Des diet got the best ingestion level for 131.2 $\pm 8.3 \mathrm{~g}$ DM, followed by Pan diet

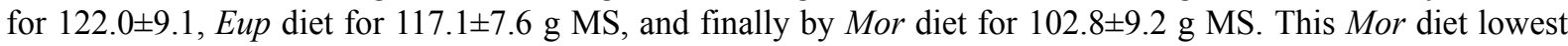
ingestion level could be explained by Moringa oleifera inappetence because the plant was harvested and distributed on the same day, without any pre-drying.

Indeed, the feed presentation is an important factor modulating rabbits' ingestion. According to Gidenne and Lebas (2005), in free choice, rabbits prefer pellet feed for 97\%. In fact, pellet feeds are compact and dry (Kpodékon et al., 2009; Lebas, 2007). The pellet benefits from a fine grain size of its particles size due to the grinding and nutritional values. For example, pellets are made of minerals, vitamins, and amino acids of plant or animal origin, dried coconut, and cotton cake which are used as protein sources. Thus, when rabbits have a choice, they derive greater profit from it (Kouakou et al., 2016). Indeed, the rabbit digests fine particles better than coarse particles (Gidenne \& Lebas, 2005). During digestion transit through the large intestine muscle, rabbits' practice fine particles retention selective fluids through colon walls which separates particles according to their size (Sakaguchi, 2003). Then, the pellet small amount in the Eup diet will lead to a large amount of Euphorbia heterophylla ingestion, to fill its energy need. However, because of the stomach congestion phenomenon, the fresh forage ingestion capacity is fundamentally limited (Kouakou et al., 2016).

All diets induced an increase in daily weight gain for rabbit-does (Table 3). This increase was significantly elevated $(\mathrm{P}<0.05)$ with rabbit does fed on Pan diet based on Panicum maximum and rabbit mixed concentrate pellets for $15.7 \pm 6.1 \mathrm{~g}$ and Desmodium tortuosum (Des) diet for $17.4 \pm 6.3 \mathrm{~g}$. These two diets showed no difference, so the average was $16.55 \mathrm{~g}$. However, the Eup and Mor diets were significantly lower than the two previous diets $(\mathrm{P}<0.05)$, but identical to each other $(\mathrm{P}>0.05)$, for $5.3 \pm 5.2 \mathrm{~g}$ and $7.0 \pm 4.0 \mathrm{~g}$, respectively. 
Table 3. Dry matter (DM), metabolizable energy (M.E), and crude protein (CP) daily voluntary ingestion, and rabbit does weight average daily weight gain (ADWG) during gestation and lactation periods



Note. Results are given as Mean (SD), SD: standard deviation. The means in the same row followed by the same lowercase letter are not significantly different.

ADWG: Average daily weight gain; VDIME: voluntary daily intake of metabolizable energy; VDICP: voluntary daily intake of crude protein.

Ingredients: g/d: gram per day; Pel.: mixed type pellet for rabbits; Pan. max.: Panicum maximum; D. tor: Desmodium tortuosum; E. het.: Euphorbia heterophylla; M. ole.: Moringa oleifera.

Diets: Pan: P. maximum $+\mathrm{FACI}^{\odot}$ mixed type pellet for rabbits; Eup: P. maximum + E. heterophylla $+\mathrm{FACI}^{\odot}$ mixed type pellet for rabbits; Des: $P$. maximum $+D$. tortuosum $+\mathrm{FACI}^{\odot}$ mixed type pellet for rabbits; Mor: $P$. maximum + M. oleifera $+\mathrm{FACl}^{\odot}$ mixed type pellet for rabbits.

${ }^{\mathrm{a}}{ }^{\mathrm{b}}$ Means within rows of diet with no common superscript differ $(\mathrm{P}<0.05)$ by the Student Newman Keuls test.

\subsection{Apparent Digestive Utilization Coefficient}

Table 4 shows the apparent digestive utilization coefficients according to the diets. Its values were $56.6 \pm 5.3 \%$ for Pan; $62.6 \pm 5.3 \%$ for Des, $65.8 \pm 10.3 \%$ for Eup, and $62.8 \pm 8.9 \%$ for Mor. Compared to Pan diet, the green forages addition to $P$ an reference diet improved the coefficient. These apparent digestive utilization coefficients were significantly lower $(\mathrm{P}<0.05)$ for Pan diet than those of Des, Eup and Mor diets. Within the green forage diets, the apparent digestive utilization coefficients did not differ significantly $(\mathrm{P}>0.05)$, leading to a $63.73 \%$ average. So, adding the green forage to Panicum and rabbit mixed pellet ingredients increases the feed conversion ratios. 
Table 4. Diets apparent digestive utilization ratio $(\% \mathrm{DM})$

\begin{tabular}{lllll}
\hline \multirow{2}{*}{ Designation } & \multicolumn{4}{c}{ Diets } \\
\cline { 2 - 5 } & Pan & Des & Eup & Mor \\
\hline Dry matter intake (g/kg DM) & $115.6(5.9)^{\mathrm{b}}$ & $126.8(8.2)^{\mathrm{a}}$ & $117.6(6.2)^{\mathrm{b}}$ & $116.0(11.6)^{\mathrm{b}}$ \\
Droppings dry matter (g/kg DM) & $51.3(6.3)^{\mathrm{a}}$ & $47.4(7.4)^{\mathrm{a}}$ & $40.4(12.9)^{\mathrm{a}}$ & $42.6(8.5)^{\mathrm{a}}$ \\
Apparent digestive utilization coefficient (\%DM) & $55.6(5.3)^{\mathrm{b}}$ & $62.6(5.3)^{\mathrm{a}}$ & $65.8(10.3)^{\mathrm{a}}$ & $62.8(8.9)^{\mathrm{a}}$ \\
\hline
\end{tabular}

Note. Results are given as Mean (SD), SD: standard deviation.

a ${ }^{\mathrm{b}}$ Means within a row with different superscript differ $(\mathrm{P}<0.05)$ by the Student Newman Keuls test.

In family rabbit farming, breeders are looking for a substantial feed reduction costs, by keeping the optimal animals' growth. If possible, this goal can be achieved by distributing coarse fodder, or whole green plants, or dried plants' parts (Kpodékon et al., 2009). So, Kadi et al. (2012) argued that it is important to know about plants palatability for rabbits, their intake, and digestion levels. These apparent digestive utilization coefficients were close to Goby et al. (2017) findings. During their experiment, Goby et al. (2017) used fresh whole carrot, dry whole carrot, and alfalfa hay. They concluded that fresh whole carrot was better digested (85\%) than dehydrated forage (56\%). In addition, the dry matter ingested quantities from the alfalfa hay was $22 \%$ less than the carrot group dry matter intake. Thus, with this alfalfa hay, the intake was $25 \%$ below the rabbit's maximum ingestion capacity, which was between 70 and $80 \mathrm{~g}$ DM per day.

Nevertheless, although the rabbits had high digestion between 62.6 to $65.8 \%$ for Des, Eup, and Mor; and adequate intake 116 to $126.8 \mathrm{~g}$ DM per day for the same diets, the rabbit does weight loss (Table 3) were significant and higher than $9 \mathrm{~g}$ per day. This situation could be explained in part by an insufficient sulfur amino acid intake on average in experimental forages because green forage content for this nutrient is around $2 \%$ for $3.7 \%$ desirable intake. Also, weight losses were due to the high demand for both energy and protein in lactation (Bonnet, 2006). In Pan diet, the mineral deficits were corrected by the rabbit concentrated and mixed pellets. So, Pan diet rabbit does weights losses were minimized. These results agree with Kouakou et al. (2016) findings.

\subsection{Rabbit Does Reproduction Parameters}

After farrowing, rabbit does weights were $2966.9 \pm 174.2 ; 3032.4 \pm 167.3 ; 2957.8 \pm 159.1$ and $2999.3 \pm 166.9 \mathrm{~g}$, respectively for rabbit does fed on Pan, Des, Eup, and Mor diets (Table 5). Because we constituted homogeneous groups in weight before matting, these weights after farrowing did not differ significantly by diet $(\mathrm{P}>0.05)$. Fertility rates were $66.6 \% ; 83.3 ; 83.3 \%$ and 50\%, respectively, for Pan, Des, Eup, and Mor diets. The number of pups born alive per diet was 96, 112, 112, and 76 from rabbit-does fed on Pan, Des, Eup, and Mor diets, respectively. According to Houindo (2002), rabbit does fertility is $61 \%$ in primiparous, and $50 \%$ in multiparous. Moreover, herein results were significantly higher than those of Houindo (2002), except for Mor diet (50\%). As Toleba et al. (2017) findings, when they incorporated Neem leaves (Azadirachta Indica) in rabbit does' diets at an $8 \%$ incorporation rate, they got $100 \%$ females farrowing. Pan diet fertility result was lower than those of Des and Eup diets. Both diets improved Pan diet fertility by $25.07 \%$, from $66.6 \%$ to $83.3 \%$. Unfortunately, Mor diet depressed Pan diet fertility rate by $24.93 \%$, from $66.6 \%$ to $50 \%$. Altogether, Des and Eup diets outputs were $66.6 \%$ better than that of Mor diet.

Average litter sizes and average pups' weights were $6.0 \pm 1.8 ; 5.6 \pm 2.2 ; 5.6 \pm 1.1$ and $6.3 \pm 2.1$ rabbits, $50.2 \pm 8.9$; $56.1 \pm 11.3 ; 54.3 \pm 12.7$ and $49.2 \pm 11.8$ g, respectively for Pan, Des, Eup, and Mor diets. These litter sizes and their weights did not differ significantly $(\mathrm{P}>0.05)$. So, rabbit-does farrowed $5.87 \mathrm{pups}$, and the litter weighed $52.45 \mathrm{~g}$ in average. Similarly, Akpo et al. (2008) announced 5.7 pups per litter.

\subsection{Milk Production}

The milk production during the lactation peak period showed some variations. Indeed, peak lactation milk production under Eup diet (140.0 \pm 5.4$)$ had a higher average milk yield than Des diet $(\mathrm{P}<0.05)$. However, Mor diet production was median between Eup and Des (Table 6) and therefore did not differ significantly $(\mathrm{P}>0.05)$ from either Eup or Des. In addition, rabbits on Pan diet produced significantly less milk than the other three diets $(\mathrm{P}<0.05)$. Pups weight changes at peak lactation in Des and Eup diets were greater than those of Pan and Mor diets $(\mathrm{P}>0.05)$. Thus, these two groups Des and Eup on one hand, and Pan and Mor on the other hand were similar in pairs $(\mathrm{P}>0.05)$ to each other for this growth performance. Pups average weaning weights did not differ significantly. The pups daily weight gains at lactation peak were $6.3 \pm 0.3 \mathrm{~g} / \mathrm{d}, 6.6 \pm 0.3 \mathrm{~g} / \mathrm{d}$, and $5.8 \pm 0.8 \mathrm{~g} / \mathrm{d}$ for Pan, Eup, and Mor pups, respectively, and did not differ significantly $(\mathrm{P}>0.05)$. 
Table 5. Rabbit does reproduction parameters

\begin{tabular}{lllll}
\hline \multirow{2}{*}{ Parameters } & \multicolumn{4}{c}{ Diets } \\
\cline { 2 - 5 } & Pan & Des & Eup & Mor \\
\hline Rabbit does number & 24 & 24 & 24 & 24 \\
Rabbit does weight at matting & $3006.3(132.5)^{\mathrm{a}}$ & $2999.0(140.9)^{\mathrm{a}}$ & $3030.0(124.2)^{\mathrm{a}}$ & $2990.7(126.4)^{\mathrm{a}}$ \\
Number of rabbit-does having farrowed & 16 & 20 & 20 & 12 \\
Rabbit does weight after farrowing (g) & $2966.9(174.2)^{\mathrm{a}}$ & $3032.4(167.3)^{\mathrm{a}}$ & $2957.8(159.1)^{\mathrm{a}}$ & $2999.3(166.9)^{\mathrm{a}}$ \\
Total pup number & 96 & 112 & 112 & 76 \\
Litter size & $6.0(1.8)^{\mathrm{a}}$ & $5.6(2.2)^{\mathrm{a}}$ & $5.6(1.1)^{\mathrm{a}}$ & $6.3(2.1)^{\mathrm{a}}$ \\
Pups' weights (g) & $50.2(8.9)^{\mathrm{a}}$ & $56.1(11.3)^{\mathrm{a}}$ & $54.3(12.7)^{\mathrm{a}}$ & $49.2(11.8)^{\mathrm{a}}$ \\
Fertility rate (\%) & 66.6 & 83.3 & 83.3 & 50 \\
\hline
\end{tabular}

Note. Results are given as Mean (SD), SD: standard deviation.

${ }^{\mathrm{a}},{ }^{\mathrm{b}}$ Means within a row with different superscript differ $(\mathrm{P}<0.05)$ by the Student Newman Keuls test.

Singularly, pups' weights from rabbit does fed on Des had the heaviest weights at peak lactation, and this weight was significantly higher than those of Pan, Eup, and Mor diets. At weaning period, Pan, Des, and Eup delivered the best average daily weight gain for $6.2 \pm 0.5,6.4 \pm 0.6$, and $6.4 \pm 0.4$, respectively, compared to $5.4 \pm 06 \mathrm{~g}$ for Mor diet $(\mathrm{P}<0.05)$. According to Kunnath et al. (2018), genetic group, birth season, and litter size have a significant influence on rabbit pups daily weight gain. This assertion is supported by Sherif (2018) findings. When Sherif (2018) used New Zealand white rabbits in Egypt, he got $27.2 \mathrm{~g}$ daily, which is 4.5 times higher than Cote d'Ivoire local breed performance. Similarly, when Omer et al. (2012) used some green forage, he got $30.36 \mathrm{~g} / \mathrm{d}$ with New Zealand white rabbits. In relatively cool temperatures, the rabbits grow faster than under humid tropical conditions. So, this daily weight gain was distributed in a large interval. Moreover, feed presentation such as pellet, forage, or mash, and feed dietary lignin level affect significantly rabbit growth Gidenne et al. (2015). For example, when Akande (2015) added some roasted pigeon pea meal in the rabbit diet at 10, 20, and $30 \%$, the daily weight gain decreased from 16 to 13 , and $12 \mathrm{~g}$, respectively. Again, Di-Meo et al. (2004) observed a daily weight gain between 13 and $14 \mathrm{~g}$. Due to the high-temperature effect, Kunnath et al. (2018) got an average daily weight gain ranged from 8.86 to $29.52 \mathrm{~g}$. So, the present experiment results were quite acceptable.

Table 6. Rabbit does milk production and pup rabbits' weight at peak lactation

\begin{tabular}{lllll}
\hline \multirow{2}{*}{ Designations } & \multicolumn{4}{c}{ Diets } \\
\cline { 2 - 5 } & Pan & Des & Eup & Mor \\
\hline Daily rabbit does milk production (g) & $109.6(4.9)^{\mathrm{c}}$ & $126.6(5.1)^{\mathrm{b}}$ & $140.0(5.4)^{\mathrm{a}}$ & $131.5(6.6)^{\mathrm{ab}}$ \\
Pup weights at lactation pic (g) & $187.4(2.1)^{\mathrm{b}}$ & $195.7(3.2)^{\mathrm{a}}$ & $192.0(2.0)^{\mathrm{a}}$ & $185.6(1.6)^{\mathrm{b}}$ \\
Pup weaning weights (g) & $230.7(5.4)$ & $227.7(4.4)$ & $236.7(2.5)$ & $223.3(2.1)$ \\
Daily weight gain at lactation pic (g/d) & $6.3(0.3)^{\mathrm{b}}$ & $6.9(0.2)^{\mathrm{a}}$ & $6.6(0.3)^{\mathrm{b}}$ & $5.8(0.8)^{\mathrm{b}}$ \\
Pup daily weight gain at weaning (g/d) & $6.2(0.5)^{\mathrm{a}}$ & $6.4(0.6)^{\mathrm{a}}$ & $6.4(0.4)^{\mathrm{a}}$ & $5.4(0.6)^{\mathrm{b}}$ \\
\hline
\end{tabular}

Note. Results are given as Mean (SD), SD: standard deviation.

g/d: gram per day.

${ }^{\mathrm{a}},{ }^{\mathrm{b}}$ Means within a row with different superscript differ $(\mathrm{P}<0.05)$ by the Student Newman Keuls test.

The feed composition is one of the main factors that influence rabbit does milk production. In addition to milk production quantity, its fat contents are also impacted (Pascual et al., 2003). Indeed, when Kowalska and Bielanski (2004) used the linseeds, the 4\% linseed oil mixture did not only improve the milk production quantity, but it affected also the saturated fatty acid profile, which reflects a high fatty acids transfer rate. This close link between the feed fatty acid composition (especially omega 3) and milk has also been demonstrated by Castellini et al. (2004). Therefore, the best rabbit does milk production fed on Des, Eup, and Mor diets was probably due to these diets galactogenic activities (Oguike \& Udeh, 2008). These plants galactogenic activities would be due to their ability to stimulate the secretion of the hormones, which could induce milk synthesis, particularly prolactin (Akouedegni et al., 2013). Indeed, polymers from plants including galacturonic acid and $\beta$-glucan are considered 
hormones or hormone messengers in plants. This suggests that animal cells are also sensitive to these hormonal messengers (Sawadogo et al., 1989).

In addition, some plants used by farmers to increase milk production in cattle in Benin are mainly from leguminosae family, Moraceae, and Euphorbiaceae. Then, these plants use belonging to these families, are known in the traditional environment for their lactogenic power (Akouedegni et al., 2012). Undoubtedly, the daily milk quantities obtained from rabbits does fed on Des, Eup, and Mor diets for 126.6 $\pm 29.1,140.0 \pm 31.4$, and $131.5 \pm 29.6 \mathrm{~g}$, respectively, could be associated with these plants' intrinsic activities. In fact, they induce a good milk production, via the consequently prolactin secretion. According to Mosango (2008), and Sulistiawati et al. (2017), Euphorbia heterophylla and Moringa oleifera leaves' capsules contain phytosterol chemicals (poliferol and sterols), saponins, phenols, and terpenes including phorbolic diterpenes, whose play an important role in increasing prolactin levels. Indeed, prolactin plays an essential role in mammary gland growth and milk secretion induction (Akouedegni et al., 2013). An increase in this hormone concentration and an increase in lactocytes exposure duration to this same hormone will lead to an increase in the number of the receptors on the lactocytes membrane. Under these conditions, milk will be continuously secreted under the autocrine control of these lactocytes. Moreover, the milk production by these lactocytes will depend on the milk quantity they contain (Akouedegni et al., 2013). Similarly, these observations were made by Kiranawati and Nurjanah (2014), when they substituted Moringa oleifera leaf flour in experimental diets. Thus, in vivo in Wistar rabbits (Rattus norvegicus), they observed significantly more developed mammary glands later on, in contrary to the control congeners.

Desmodium tortuosum is still a little-known forage plant. Meanwhile, considering the dairy production performance of the rabbit does fed on it, Desmodium tortuosum is undeniably an excellent green forage. As Morris et al. (2014), during flavonoid concentrations determination, D. tortuosum produced $718 \mu \mathrm{g} / \mathrm{g}$ isorhamnetin. Screening D. discolor, D. incanum, D. intortum, D. sandwicense, and D. tortuosum, and their oil content and its fatty acid composition, Morris et al. (2014) concluded that Desmodium species could be used as alternatives livestock health products. According to Chibah-Ait et al. (2015), rabbit does milk production is important when the pup group size is large. Due to the temperature adverse effect on rabbit does milk production (Hue-Beauvais et al., 2015; Szendrö et al., 1999; Zerrouki et al., 2014), the present milk production results could have been better. In fact, Szendrö et al. (1999), Zerrouki et al. (2014), and Hue-Beauvais et al. (2015) demonstrated that rabbit does have difficulties in adapting to temperatures equal or higher than $30{ }^{\circ} \mathrm{C}$, which significantly reduces their ability to produce milk. In addition, the lactogenic power attributed to certain plants would be due to nutritional intake and prolactin stimulating substances joint action in the pituitary gland (Adepo et al., 2010; Sepehri et al., 2000). According to Deleke Koko et al. (2011), specific lactogenic compounds plants are terpenes, steroids, flavonoids, and cardiotonic derivatives. Ouedraogo et al. (2004) stated that the conjugated chemical compounds groups action would be at the origin of the plants' galactogenic properties.

\section{Conclusion}

This work results show that Desmodium tortuosum, Euphorbia heterophylla, and Moringa oleifera associated with commercial rabbit pellet diets digestion is higher than $62 \%$. While, the pellets should not be associated only with Panicum maximum, because this diet digestibility was 55\%. Most importantly, these fresh weeds and commercial pelleted feed mixtures did not adversely affect the rabbits' performances. Specifically, commercial pellets for rabbits and Panicum maximum diets containing Desmodium tortuosum, Euphorbia heterophylla, and Moringa oleifera green forages had a very good galactogenic effect. So, Desmodium tortuosum and Euphorbia heterophylla were better than Moringa oleifera and could be used as green forages to improve milk production in local rabbit does breeding. It would be important to determine the active substances responsible for this galactogenic effect in these plants and to establish a correlation with milk production. Nevertheless, these results could be supported by assays on certain lactation hormones including prolactin and growth hormone in blood plasma. Also, blood cell counts, triglyceride, total and HDL cholesterols determination could provide some information on the animals' health status.

\section{References}

Adepo, Y. P., Assi, S., Biégo, H. G., Chatigre, K. O., \& Kati, C. S. (2010). Étude de l'évolution des paramètres physico-chimiques de 2 plantes Euphorbia hirta et Secamone afzelii en fonction des quatre saisons de l'année, de l'extraction aqueuse et évaluation du pouvoir lactogène. Bulletin de la Société Royale des Sciences de Liège, 79, 12-24.

Akande, K. E. (2015). Dietary Effects of Increasing Levels of Pigeon Pea Meal on Rabbit Performance. Journal of Agricultural Science, 7(7), 156-162. https://doi.org/10.5539/jas.v7n7p156 
Akouedegni, C. G., Gbégo, T. I., Daga, F. D., Koudandé, D. O., \& Hounzangbé-Adoté, M. S. (2012). Synthèse des connaissances sur les plantes galactogènes et leurs usages en République du Bénin. Bulletin de la Recherche Agronomique du Bénin (BRAB), Numéro Spécial Productions Végétales \& Animales et Economie \& Sociologie Rurales (pp. 24-35). Retrieved from http://www.slire.net/download/2126/article_3 akoued_gni_et_al_plantes_galacto_brab_n_sp_cial_prod_v_an_co_soc_rur_d_c_2012.pdf

Akouedegni, C. G., Koudande, O. D., Ahoussi, E., \& Hounzangbe-Adote, M. S. (2013). Effects of the fresh leaves of Spondias mombin L. on milk production of West African Dwarf (WAD) ewes and their lamb's growth performance. Journals of Animal Science Advances, 3(2), 74-82. https://doi.org/10.5455/jasa.2013 0219104112

Akpo, Y., Kpodékon, T. M., Tanimomo, E., Djago, A. Y., Youssao, A. K. I., \& Coudert, P. (2008). Evaluation of the reproductive performance of a local population of rabbits in south Benin (pp. 29-34). 9th World Rabbit Congress, June 10-13, 2008, Verona, Italy.

AOAC. (1990). Official Methods of Analysis, Agricultural Chemicals, Contaminants, Drugs (15th ed., Vol. 1).

Bonnet, O. (2006). Elaboration d'un protocole de visite d'elevage des rongeurs et lagomorphes de compagnie (Thèse de Doctorat en Médecine Vétérinaire, Université Claude-Bernard-Lyon I).

Castellini, C., Dal-Bosco, A., Cardinali, R., Mugnai, C., \& Sciascia, E. (2004). Effect of dietary $n 3$ fatty acids on the composition of doe's milk and tissues of suckling rabbits (pp. 771-777). 8th World Rabbit Congress.

Chibah-Ait, B. K., Zerrouki-Daoudi, N., \& Lebas, F. (2015). Effet de la taille de portée à la naissance et du nombre de lapereaux allaités sur les aptitudes laitières des lapines de deux génotypes (pp. 89-92). 16 èmes Journées de la Recherche Cunicole in E-book_JRC_2015, 24-25 Novembre 2015, Le Mans, France.

Codjia, J. T. C., Fonton, K. B., Assogbadjo, A. E., \& Ekue, M. R. M. (2001). Le baobab (Adansonia digitata) une espèce à usages multiple au Bénin. CECODI, CBDD, VeCo, SNV, FSA: Cotonou.

Deleke-Koko, I. K. E., Djego, J., Gbenou, J., Hounzangbe-Adote, S. M., \& Sinsin, B. (2011). Etude phytochimique des principales plantes galactogènes et emménagogues utilisées dans les terroirs riverains de la Zone cynégétique de la Pendjari. International Journal of Biological and Chemical Sciences, 5(2), 618-633. https://doi.org/10.4314/ijbcs.v5i2.72127

Di-Meo, C., Gazaneo, M. P., Racca1, C., Bovera, F., Piccolo, G., \& Nizza, A. (2004). Effect of Birth Weight and Litter Size on Productive Performance of Rabbits. Asian-Australasian Journal of Animal Sciences, 17(8), 1158-1161. https://doi.org/10.5713/AJAS.2004.1158

FAO. (2003). Food Energy-Methods of Analysis and Conversion Factors, Report of a Technical Workshop, Rome, December 3-6, 2002. Food and Nutrition Sciences, 77, 93.

Fernández-Carmona, J., Alqedra, I., Cervera, C., Moya, J., \& Pascual, J. J. (2003). Effect of lucerne-based diets on performance of reproductive rabbit does at two temperatures. Journal of Animal Science, 76, $283-295$. https://doi.org/10.1017/S1357729800053534

Gidenne, T., \& Lebas, F. (2005). Le comportement alimentaire du lapin. 11 èmes Journées de la Recherche Cunicole, 29-30 Novembre 2005, Paris.

Gidenne, T., Lebas, F., Savietto, D., Dorchies, P., Duperray, J., Davoust, C., \& Lamothe, L. (2015). Chapitre 5: Nutrition et alimentation. In T. Gidenne (Ed.), Le Lapin: De la biologie à l'élevage (pp. 139-184). Editions Quae Versailles, France.

Goby, J. P., Coullet, S., Huck, C., Bannelier, C., \& Gidenne, T. (2017). Ingestion et digestion de fourrages secs et verts pour le lapin: Première approche pour la luzerne et la carotte en-tière (pp. 197-200). 17 èmes Journées de la Recherche Cunicole, 21 et 22 Novembre 2017, Le Mans, France.

Houindo, E. (2002). Effets du rang de mise-bas sur la fertilité des lapines au Sud et au Centre du Bénin. Mémoire de fin d'étude pour l'obtention du Diplôme d'Ingénieur des Travaux, Université d'Abomey-Calavi, Bénin (p. 66).

Hue-Beauvais, C., Koch, E., Chavatte-Palmer, P., Galio, L., Chat, S., Letheule, M., ... Aujean, E. (2015). Milk from dams fed an obesogenic diet combined with a high-fat/high-sugar diet induces long-term abnormal mammary gland development in the rabbit. Journal of Animal Science, 93, 1641-1655. https://doi.org/ $10.2527 /$ jas.2014-8139 
Kadi, S. A., Belaidi-Gater, N., Oudai, H., Bannelier, C., Berchiche, M., \& Gidenne, T. (2012). Nutritive value of fresh Sulla (Hedysarum flexuosum) as a sole ration for growing rabbits. 10th World Rabbit Congress, September 3-6, 2012, Sharm El-Sheikh, Egypt.

Kiranawati, T. M., \& Nurjanah, N. (2014). Improvement of Noodles Recipe for Increasing Breastmilk Design of the Moringa Noodles. American Journal of Food Science and Technology, 2(3), 88-92. https://doi.org/ 10.12691/ajfst-2-3-2

Koné, G. A., Good, M., \& Kouba, M. (2020). Performance of guinea fowl fed hevea seed meal or cashew nut meal as a partial substitute for soya bean meal. Animal, 14(1), 206-214. https://doi.org/10.1017/S175173 $111900185 \mathrm{X}$

Kouakou, N. D. V., Kouakou, N. J. A., Iritié, B. M., Adjiadjemian, S. B., Diarrassouba, Z., N’Guessan, K. R., \& Kouba, M. (2015). Effet de l'herbe de Guinée (Panicum maximum Jacq.) associée à l'herbe de lait (Euphorbia heterophylla L.) ou aux feuilles de patate douce (Ipomoea batatas (L.) Lam) sur la croissance des lapins (Oryctolagus cuniculus L.). Journal of Applied Biosciences, 93, 8688-8695. https://doi.org/ 10.4314/jab.v93i1.3

Kouakou, N. D. V., Kouba, M., \& Thys, E. (2016). Étude comparative de la digestibilité in vivo de l'herbe de Guinée (Panicum maximum Jacq.) associé aux feuilles et tiges de patate douce (Ipomea batata (L.) Lam) ou à l'herbe de lait (Euphorbia heterophylla L.) chez le lapin (Oryctolagus cuniculus L.) et le cobaye (Cavia porcellus L.). Tropicultura, 34(2), 158-165.

Kouassi, G. F., Kouakou, N. D. V., Coulibaly, S. B. M., Koné, G. A., Koffi, K. F., Kouassi, A. J. F., \& Amoikon, K. E. (2017). Potentialités Hypocholestérolémiantes D’Euphorbia heterophylla (L.) Klotz. \& Garcke (Euphorbiaceae) Chez Les Lapins Locaux (Oryctolagus cuniculus L.). European Scientific Journal, 13(9), 83-95. https://doi.org/10.19044/esj.2017.v13n9p83

Kowalska, D., \& Bielanski, P. (2004). Effect of supplemental dietary fat for rabbits on milk composition and rearing performance of young rabbits. Word Rabbit Science (pp. 869-873). 8th Word Rabbit Congress, Valencia, Spain.

Kpodékon, M., Youssao, A. K. I., Koutinhouin, G. B., Baba, I. L., Dessou, J. M., \& Djago, Y. (2009). Effet de la granulation sur les performances de croissance, l'efficacité alimentaire et la viabilité des lapereaux en condition d'élevage tropical. Revue d'Elevage et de Médecine Vétérinaire des Pays Tropicaux, 62, 75-80. https://doi.org/10.19182/remvt.10097

Kunnath, S., Durgam, S., Manthani, G., \& Amaravadhi, S. (2018). Study on Pre-weaning Growth Performance of Broiler Rabbit Breeds. International Journal of Livestock Research, 8(9), 234-240. https://doi.org/ 10.5455/ijlr.20171205103612

Lebas, F. (1971). Composition chimique du lait de lapine, évolution au cours de la traite et en fonction du stade de lactation. Annales de Zootechnie, 20(2), 185-191. https://doi.org/10.1051/animres:19710205

Lebas, F. (2007). Plantes tropicales utilisables comme fourrages pour les lapins. Méthodes et techniques d'élevage du lapin en milieu tropical (p. 84).

Morris, J. B., Wang, M. L., \& Tonnis, B. (2014). Desmodium genetic resources for improving flanoïd concentrations, oil content and fatty acid composition. Plants Genetic Resources: Characterization and Utilization, 12(1), 120-128. https://doi.org/10.1017/S1479262113000397

Mosango, D. M. (2008). Euphorbia heterophylla L. In G. H. Schmelzer \& A. Gurib-Fakim (Eds.), Medicinal plants/Plantes médicinales 1. PROTA, Wage-ningen, Netherlands.

Oguike, M. A., \& Udeh, N. A. (2008). Influence of ethnovetenary plant Spondias mombin L. on partial daily milk yield (PDM), Haematology and serum biochemistry of lactating West Africa Dwarf ewes. Journal of Animal and Veterinary Advences, 7(5), 585-588.

Omer, H. A. A., Ibrahim, A. M., Abedo, A. A., \& Ali, F. A. F. (2012). Growth Performance of Rabbits Fed Diets Containing Different Levels of Energy and Mixture of Some Medicinal Plants. Journal of Agricultural Science, 4(2), 101-112. https://doi.org/10.5539/jas.v4n2p201

Ouedraogo, Z. L., Heide, D. V. D., Beek, E. M. V. D., Swarts, H. J. M., Mattheij, J. A. M., \& Sawadogo, L. (2004). Effect of aqueous extract of Acacia nilotica ssp adansonii on milk pro-duction and prolactin release in the rat. Journal of Endocrinology, 182, 257-266. https://doi.org/10.1677/joe.0.1820257 
Pascual, J. J., Cervera, C., Blas, E., \& Fernández-Carmona, J. (2003). High energy diets for reproductive rabbit does: Effect of energy source. Nutrition Abstracts and Reviews, 73(5), 27R-39R.

Sakaguchi, E. (2003). Digestive strategies of small hindgut fermenters. Animal Science Journal, 74(5), 327-337. https://doi.org/10.1046/j.1344-3941.2003.00124.x

Sawadogo, L., Sepehri, H., \& Houdebine, L. M. (1989). Mise en évidence d'un facteur stimulant la sécrétion de prolactine et de l'hormone de croissance dans les drèches de brasserie. Journal de Reproduction, Nutrition, Developpement, 29, 139-146. https://doi.org/10.1051/rnd:19890202

Sepehri, H., Kann, G., \& Houdebine, L. M. (1992). Pouvoir lactogènes potentiel de quelques extraits de plantes iraniennes. Cahiers Agricultures, 1(1), 35-39.

Sepehri, H., Zoraghi, R., \& Haeri-Rohani, A. (2000). Effect of pectic acid and $\beta$-glucan on prolactin secretion by ovine pituitary explants. Iranian Journal of Science, 1, 99-107.

Sherif, S. K. (2018). Effect of dietary additives on growth performance, carcass traits and some blood constituents of rabbits. Journal of Agricultural Science, 10(1), 139-151. https://doi.org/10.5539/ jas.v10n1p139

Sulistiawati, Y., Suwondo, A., Hardjanti, T. S., Soejoenoes, A., Anwar, M. C., \& Susiloretni, K. A. (2017). Effect of moringa oleifera on level of prolactin and breast milk production in postpartum mothers. Belitung Nursing Journal, 3(2), 126-133. https://doi.org/10.33546/bnj.75

Szendrö, Z., Papp, Z., \& Kustos, K. (1999). Effect of environmental temperature and restricted feeding on production of rabbit does. Proc. of 2nd Int. Conf. on Rabbit Production in Hot Climates. Cahiers Options Méditerranéennes, 41, 11-17.

Toleba, S. S., Dahouda, M., Haziz Sina, V. S. D., Natonnagnon, U., Harouna, A., Adenile, A. D., ... Baba-Moussa, L. (2017). Ingestions alimentaires et Performances de production et de reproduction des lapines (Oryctolagus cuniculus) gestantes nourries avec des aliments contenant des feuilles de neem (Azadirachta indica). European Scientific Journal, 13(15), 82-100. https://doi.org/10.19044/esj.2017. v13n15p82

Yapo, A. F., Edjeme-Aké, N. A., Yéo, D., Yapi, H. F., N’Guessan, J. D., \& Djaman, A. J. (2012). Hepatic and Glucose Biotolerance Induced by the Aqueous Extract of Leaf of Parkia biglobosa in Rabbit. Journal of Asian Scientific Research, 2(4), 189-199.

Zerrouki, N., Chibah, K., Amroun, T., \& Lebas, F. (2012). Effect of the average kits birth weight and of the number of born alive per litter on the milk production of algerian white population rabbit does (pp. 351-355). 10th World Rabbit Congress-September 3-6, 2012, Sharm El-Sheikh, Egypt.

Zerrouki, N., Lebas, F., Gacem, M., Meftah, I., \& Bolet, G. (2014). Reproduction performance of a synthetic rabbit line and rabbit of local populations in Algeria in 2 breeding locations. World Rabbit Science, 22, 269-278. https://doi.org/10.4995/wrs.2014.2129

\section{Copyrights}

Copyright for this article is retained by the author(s), with first publication rights granted to the journal.

This is an open-access article distributed under the terms and conditions of the Creative Commons Attribution license (http://creativecommons.org/licenses/by/4.0/). 